\title{
PENGEMBANGAN METODE PENENTUAN KELAMIN SECARA DINI BERBASIS MOLEKULER \\ PADA TANAMAN SALAK DIOECIOUS
}

\begin{abstract}
Abstrak
Salak merupakan tanaman buah tropik yang memiliki nilai ekonomi dengan tipe pembungaan dioecious, monoecious, dan hermaprodit. Salak dioecious yang dibudidayakan membutuhkan tanaman betina dan jantan dengan rasio 4:1. Penentuan kelamin salak dioecious secara dini menjamin rasio kelamin betina dan jantan, karena pada stadia bibit sulit untuk membedakan kelamin tanaman baik secara morfologi, isozim, dan kromosom. Penentuan kelamin berbasis molekuler dengan teknik PCR-RAPD lebih akurat. Seleksi dari 305 primer dengan metode Bulked Segregant Analysis (BSA) terdapat 35 primer kandidat sebagai pembeda kelamin tanaman salak dioecious. Uji lebih lanjut secara individu dari primer kandidat ada 3 primer yang yang konsisten menghasilkan fragmen spesifik, yakni primer OPAP-20, OPO-17, dan UBC-454. Primer OPAP-20 menghasilkan fragmen terkait kelamin jantan dengan ukuran $570 \mathrm{bp}$, OPO-17 dengan fragmen berukuran 290 bp terkait kelamin betina, dan UBC-454 menghasilkan 2 fragmen spesifik, fragmen berukuran 940 bp terkait kelamin betina dan 950 bp terkait kelamin jantan. Kloning fragmen spesifik terkait kelamin tersebut menghasilkan efisiensi transformasi sekitar 95,00\%. Hasil sekuensing fragmen spesifik dihasilkan 8 pasang primer spesifik, 2 primer diantaranya dapat digunakan untuk membedakan jenis kelamin pada tanaman salak dioecious. Primer tersebut adalah J-3(1)OPO-17 mengamplifikasi fragmen 229 bp dengan tingkat akurasi 93,33\% untuk kelamin jantan, sedangkan primer B5.3 (3)UBC454 menghasilkan fragmen berukuran 356 bp dengan tingkat akurasi $95,00 \%$ untuk tanaman salak betina.

Kata kunci : diagnosis dini, kelamin, RAPD, dioecious, salak
\end{abstract}




\title{
DEVELOPMENT OF MOLECULAR BASED METHOD \\ FOR EARLY SEXUAL DETERMINATION \\ IN DIOECIOUS SALACCA
}

\begin{abstract}
Salacca is a tropical fruit crop that has various inflorescence types from monoecious, dioecious, up to hermaphrodite. Cultivation of dioecious salacca fruit requires ratio female and male plant about 4:1. Early sexual determination of dioecious salacca would guarantee the accuracy of female and male ratio because it is difficult to be distinguished at seedling stage both using its morphology, isozyme, and chromosome. Molecular based sexual determination through PCRRAPD could detect the sexual of certain crop more accurately. From 305 primers tested using bulk segregant analysis method, 35 selected primers were considered as sex marker candidates for dioecious salacca. Each primer were further analyzed individually resulting three primers with reproducible specific fragments, namely OPAP-20, OPO-17, and UBC-454. OPAP-20 resulted $570 \mathrm{bp}$ fragment related to male sex marker, while OPO-17 showed $290 \mathrm{bp}$ fragment related to the female. In contrast, UBC-454 displayed two specific fragments (940 and $950 \mathrm{bp}$ ) that related to both sexes. Cloning of all specific fragments resulted $95 \%$ efficiency. According to the result of DNA sequencing, eight pairs of specific primers were obtained and two of them (J-3(1) OPO-17 and B5.3 (3) UBC454) could be used as sex marker for dioecious salacca. Both J-3(1)OPO-17 and B5.3 (3)UBC454 were able to amplify $229 \mathrm{bp}$ (male) and $356 \mathrm{bp}$ fragments (female) with accuracy level around $93,33 \%$ and $95 \%$, respectively.
\end{abstract}

Keyword: Early determination, sex, RAPD, dioecious, salacca.

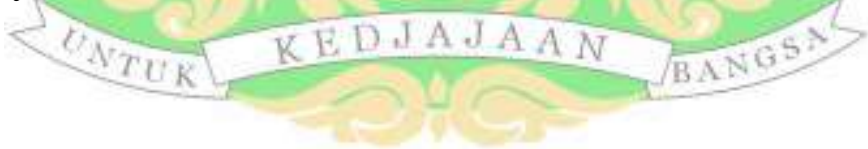

